\title{
Electrophoretic patterns of tumour tissue proteins ${ }^{1}$
}

\author{
EMIDIO AFONSO \\ From the Department of Biochemistry, Goa Medical College
}

SYNOPSIS A method of constructing pherograms is described. The study of electrophoretic patterns shown on pherograms of tumour tissue from man and animals is claimed to offer a new approach to the identification and classification of tumour tissues.

The protoplasmic proteins extracted from tissues have been separated by electrophoresis on paper and agar-gel and the patterns obtained shown to be species as well as tissue specific (Demling, 1952; Demling, Kinzlmeier, and Henning, 1954; Kessel, 1959; Scheiffarth, Goetz, and Schernthaner, 1961). It was considered interesting to study protein extracts of tumour tissues by the electrophoretic techniques previously described (Afonso, 1961, 1962), using cellulose acetate membranes as the supporting medium. Some of the results are reported here.

\section{MATERIALS}

Tumour specimens, collected soon after operation or biopsy, were stored frozen until used. Normal animal and human tissues collected soon after death were stored in the same way.

\section{PREPARATION OF EXTRACTS}

The frozen specimens were sliced by razor blade. The slices, weighing 5 to $50 \mathrm{mg}$., were quickly weighed and washed in cold saline, drained on filter paper, and transferred to a micro-version of a Potter-Elvejhem homogeniser (tube: $6 \mathrm{~cm}$. long, $4 \mathrm{~mm}$. internal diameter; piston to fit with $0.2 \mathrm{~mm}$. of clearance, connected to driving motor, speed 1,000 r.p.m.). Then 1 to 2 parts $(\mathrm{v} / \mathrm{w})$ of electrophoresis buffer were added and the slice homogenized. The homogenizer tube was centrifuged at 3,000 r.p.m. for 10 minutes. Clear supernatant was collected by a capillary pipette and used immediately.

\section{APPARATUS AND TECHNIQUE}

The best results were obtained by using the apparatus and techniques described for the separation of $\mathbf{A}_{2}$ haemoglobin (Afonso, 1962), the extract being applied by brush on the cathodic half of the acetate strip side by side with a sample of normal serum. Migration time was 20 to 25 minutes only.

'Preliminary communication.

Received for publication 11 October 1962.

\section{RESULTS}

Each pherogram shows an individual pattern which enables one tissue to be differentiated from the other and also the same tissue from different animal species (Fig. 1).

Inspection of tumour protein pherograms showed that some patterns are identifiable at a glance, for example, the fibrosarcoma (Fig. 2, 5). Some can be differentiated by the mobilities of their fractions as

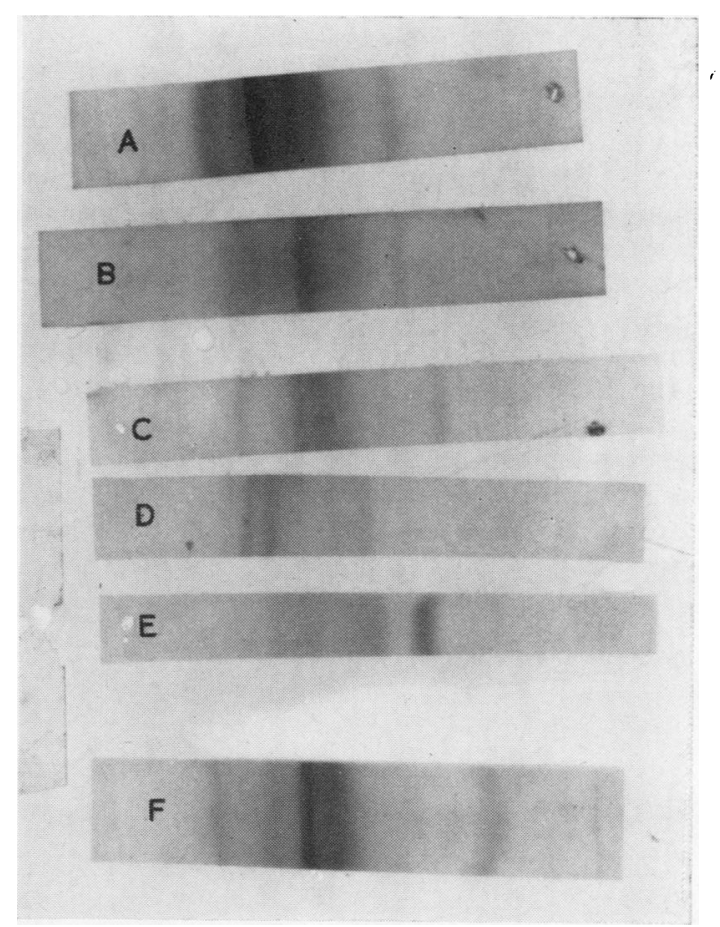

FIG. 1. Pherograms of extracts: $A=$ bovine liver, $B=$ rat liver, $C=$ human liver, $D=$ human striate muscle, $E=$ human uterine fibroma, $F=$ another sample of human liver on a longer migration time (40 minutes). 


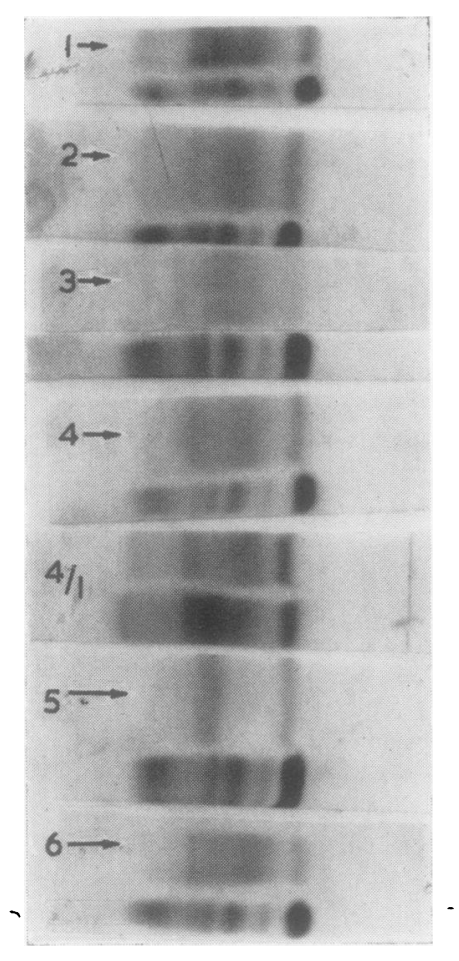

FIG. 2. Pherograms of tumour extracts run with serum. 1 Squamous cancer, alveolus;

2 epidermoid cancer, cervix;

3 adenocarcinoma colon;

4 infiltrating duct cancer, breast;

5 fibrosarcoma; and 6 epidermoid, oesophagus.

Strip 4/1 shows extracts of 4 and 1 run together to show difference in mobility of the fractions.

were the alveolar squamous cancer (Fig. 2, 1) and infiltrated duct cancer (Fig. 2, 4), which were run on the same strip (Fig. 2, 4/1) to show the difference in mobility more strikingly. The densitographic scans are also valuable aids, as shown by the striking similarity of the epidermoids (Fig. 3, B and E).

These preliminary results show that the study of electrophoretic patterns on cellulose acetate membranes presents a new approach to the study and classification of tumour tissues. The technique is simple, sensitive (needle biopsy specimens can be
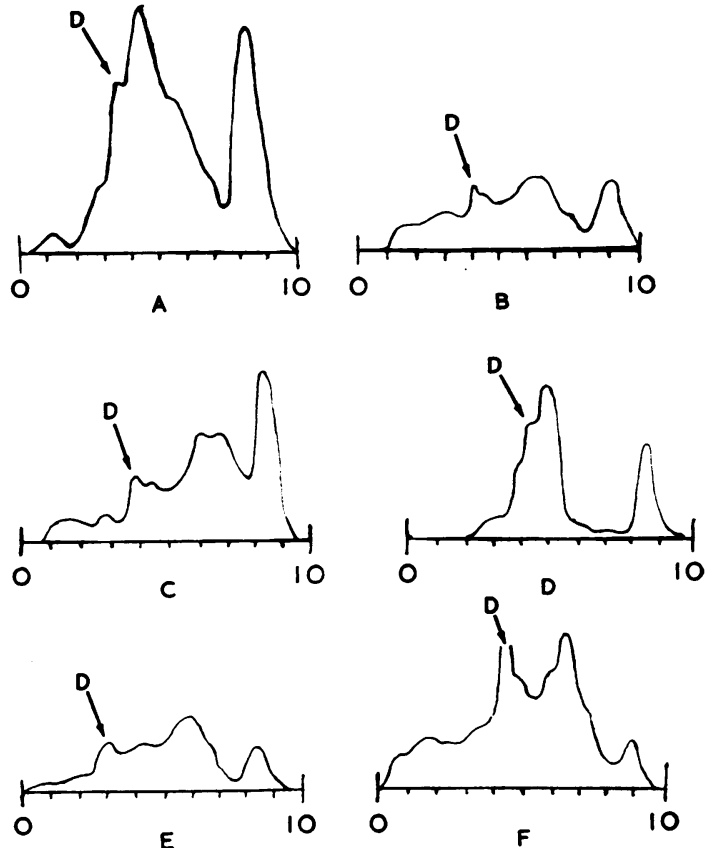

FIG. 3. Densitograms of $A$ squamous cancer, alveolus; $B$ epidermoid, cervix; $C$ infiltrating duct cancer, breast; $D$ fibrosarcoma; $E$ epidermoid, oesophagus; and $F$ adenocarcinoma, cervix.

adequately handled), and quick (a densitometric curve can be obtained within 90 minutes of operation).

\section{REFERENCES}

Afonso, E. (1961). Clin. chim. Acta, 6, 883. (1962). Ibid., 7, 545.

Demling, L. (1952). Klin. Wschr., 30, 74.

Kinzlmeier, H., and Henning, N. (1954). Z. ges. exp. Med.. $122,416$.

Kessel, M. (1959). Clin. chim. Acta, 4, 142.

Scheiffarth, F., Goetz, H., and Schernthaner, G. (1961). Ibid., 6, 481 . 